\title{
Pengembangan Rencana Pelaksanaan Pembelajaran Menggunakan Model Project Based Learning (PjBL) Pada Pembelajaran Tematik di Kelas IV SD Negeri Kota Bengkulu
}

\author{
Joko Prasetyo \\ Universitas Bengkulu \\ masjo25.com@gmail.com \\ Sri Dadi \\ Universitas Bengkulu \\ srid3154@gmail.com \\ Dwi Anggraini \\ Universitas Bengkulu \\ dwianggraini@unib.ac.id
}

\begin{abstract}
This research is motivated by the problem of the many teachers in elementary schools who have not implemented Thematic learning in the 2013 Curriculum properly. This study aims to produce a Learning Implementation Plan (RPP) using the Project Based Learning (PjBL) model in class IV Elementary Schools (SD) which can be used as a teacher's reference in implementing classroom learning. This research is a Research and Development (R\&D) study by modifying the 4-D model by Thiagarajan and Sammel. However, this research was only carried out until the third stage, namely Develop. Validation is carried out by curriculum experts. The developed lesson plans were rated and responded by 8 elementary school teachers in Bengkulu City. Data analysis techniques used descriptive statistical analysis of the results of expert validation assessment and teacher responses and qualitative descriptive analysis of comments from expert validation and teacher responses. This study produced a Thematic Learning Implementation Plan (RPP) using the PjBL model with an assessment of curriculum experts at 95.63 with a very good category and a teacher response of 87.66 with an excellent category as the final product of development.
\end{abstract}

Keywords: Learning, Development, PjBL, Thematic Implementation Plan 


\section{Pendahuluan}

Pendidikan Nasional diatur dalam Undang-Undang Republik Indonesia nomor 20 tahun 2003 pasal 3 tentang Sistem Pendidikan Nasional (UU Sisdiknas) disebutkan bahwa "Pendidikan Nasional berfungsi mengembangkan dan membentuk watak serta peradaban bangsa yang bermartabat dalam rangka mencerdaskan kehidupan bangsa, bertujuan untuk berkembangnya potensi peserta didik agar menjadi manusia yang beriman dan bertakwa kepada Tuhan Yang Maha Esa, berakhlak mulia, sehat, berilmu, cakap, kreatif, mandiri, dan menjadi warga negara yang demokratis serta bertanggung jawab". Tujuan pendidikan nasional itu merupakan rumusan mengenai kualitas manusia Indonesia yang harus dikembangkan oleh setiap satuan pendidikan. Oleh karena itu, rumusan tujuan pendidikan nasional menjadi dasar dalam pengembangan pendidikan.

Dalam rangka mencapai tujuan pendidikan nasional Indonesia diperlukan sebuah pedoman yang menjadi petunjuk dalam pelaksanaan pembelajaran. Pedoman yang digunakan sebagai acuan siswa dalam belajar adalah kurikulum. Kurikulum yang digunakan pada saat ini adalah kurikulum 2013. Dengan demikian kurikulum 2013 merupakan acuan dalam mencapai tujuan pendidikan nasional.

Penerapan kurikulum 2013 memerlukan perubahan paradigma pembelajaran, di mana peserta didik dilatih untuk belajar mengobservasi, mengajukan pertanyaan, mengumpulkan data, menganalisis data dan mengomunikasikan hasil belajar yang disebut pendekatan saintifik. Pendekatan saintifik perlu dilakukan untuk mengembangkan kemampuan peserta didik dalam belajar mandiri dan berpikir kreatif. (Sani, 2013: 7). Oleh karena itu, guru harus dapat merancang perangkat pembelajaran yang efektif dan efisien dengan memperhatikan karakteristik peserta didik dan karakteristik topik yang dipelajari berdasarkan tuntutan pembelajaran abad 21.

Kehidupan abad 21 adalah kehidupan yang tanpa batas, globalisasi, internasionalisasi, serta eksplorasi teknologi informasi dan komunikasi yang sangat mudah (Hartini, 2017). Untuk dapat menerapkan pembelajaran sesuai dengan tuntutan kurikulum 2013 dan kompetensi abad 21, guru perlu memiliki pengetahuan yang memadai tentang pendekatan saintifik, model pembelajaran, dan penilaian autentik yang digunakan dalam implementasi kurikulum 2013.

Penerapan kurikulum 2013 menggunakan pembelajaran tematik yang memiliki karakteristik berpusat pada siswa dan menempatkan siswa sebagai subjek sedangkan guru berperan sebagai fasilitator guna mengembangkan sikap, pengetahuan dan keterampilan sesuai dengan kebutuhan dan perkembangan siswa. Pembelajaran tematik merupakan salah satu pendekatan dalam pembelajaran yang merupakan suatu system pembelajaran yang memungkinkan siswa, baik secara individual maupun kelompok, aktif menggali dan menemukan konsep serta prinsipprinsip keilmuan secara holistik, bermakna dan autentik (Rusman, 2016: 139).

Permasalahan yang timbul dalam pembelajaran tematik di Sekolah Dasar adalah anak masih sulit mengubah mindsetnya dari pembelajaran dengan kurikulum KTSP menjadi pembelajaran tematik. Orang tua siswa masih belum paham tentang konsep pembelajaran tematik. Guru kesulitan dalam membuat RPP dan evaluasi karena formatnya yang selalu berubah-ubah dari pemerintah (Solekhah, 2014). Hal ini disebabkan oleh banyak faktor, salah satunya adalah penyusunan rencana pelaksanaan pembelajaran (RPP) yang tidak tepat dalam rangka membantu siswa mencapai kompetensi pada setiap pembelajaran.

Padahal menurut Hosnan (2014:2) bahwasanya kurikulum 2013 mengarahkan agar kegiatan pembelajaran dapat memberdayakan semua potensi yang dimiliki oleh siswa agar mampu memiliki kompetensi yang seimbang melalui upaya menumbuhkan serta mengembangkan ranah sikap, pengetahuan dan 
keterampilan. Perlu adanya pembenahan serta kreativitas bagi guru agar pembelajaran dapat lebih menarik siswa sebagai subjek utama pembelajaran.

Berdasarkan pengalaman peneliti pada masa pra penelitian pada tanggal 28 Januari 2020, di SD Negeri 5 Kota Bengkulu telah menggunakan kurikulum 2013. Dalam pelaksanaan pembelajaran guru belum maksimal dalam menggunakan model-model pembelajaran. Sehingga proses pembelajaran berpusat pada guru serta siswa kurang dapat mengeksplorasi kemampuan yang ada pada dirinya. Selain itu penggunaan media pembelajaran juga masih jarang dilakukan. Hal ini menunjukkan bahwa proses pembelajaran yang dilakukan guru belum mampu menampung serta memfasilitasi seluruh kemampuan belajar tiap siswa yang berbeda satu sama lain. Guru juga belum mampu mengembangan RPP tematik integratif secara maksimal. Hal ini dapat diketahui dari RPP yang dibuat oleh guru belum menggunakan model pembelajaran, karena pengetahuan guru masih kurang dalam menerapkan langkahlangkah model pembelajaran dalam RPP. Guru juga masih jarang menerapkan pembelajaran tematik integratif di kelas secara utuh, hanya berpedoman pada buku guru dan buku siswa dari kemendikbud dan jarang ada yang mengembangkan lagi.

Alasan tersebut menyebabkan guru jarang menggunakan RPP dalam melakukan kegiatan pembelajaran. Guru juga belum memahami sepenuhnya tentang pembelajaran tematik-integratif, karena selain mengintegrasikan beberapa konsep dari beberapa mata pelajaran guru juga harus mengintegrasikan nilai-nilai karakter bangsa dalam rencana dan kegiatan pembelajarannya. Untuk itu, perencanaan pembelajaran yang disusun hendaknya disesuaikan dengan perkembangan peserta didik, memperhatikan kurikulum, dan kondisi pembelajaran, sehingga model dan metode pembelajaran yang sesuai dengan perkembangan peserta didik yang tertuang dalam RPP dapat terwujud.

Selain itu, dalam buku pembelajaran tematik kelas tinggi di SD dalam setiap tema terdapat subtema 4 yang bermanfaat dalam mengembangkan kompetensi pada siswa yang salah satunya berkaitan dengan literasi proyek. Seharusnya guru mampu menerapkannya dalam pembelajaran secara efektif pada setiap semesternya, karena kegiatan pembelajaran berproyek merupakan kebutuhan siswa yang SD sedang dalam masa operasional konkret dalam kegiatan pembelajarannya. Piaget (1969) mengemukakan bahwa usia SD berkisar antara 7 sampai dengan 12 tahun. Rentang usia 7 sampai dengan 12 tahun dalam teori perkembangan Piaget dikatagorikan sebagai tahap pra operasional dan operasional konkrit. Karakter anak-anak pada tahap perkembangan pra operasional dan operasional konkrit antara lain adalah rasa ingin tahu yang tinggi, senang menerima tantangan, dan senang melakukan aktifitas fisik (Wiarsih, 2013).

Agar pembelajaran dalam literasi proyek dapat menarik siswa dalam belajar guru perlu menggunakan model yang tepat dalam proses pembelajaran. Salah satu model yang dapat digunakan dalam pembelajaran tematik agar dapat membantu siswa mencapai kompetensi yaitu dengan menggunakan model Project Based Learning (PjBL). Model $\mathrm{PjBL}$ merupakan suatu pembelajaran yang melibatkan suatu proyek dalam proses pembelajaran. Proyek yang dikerjakan oleh siswa dapat berupa proyek perseorangan atau kelompok dan dilaksanakan dalam jangka waktu tertentu secara kolaboratif, menghasilkan sebuah produk, yang hasilnya kemudian akan ditampilkan atau dipresentasikan (Rusman, 2016: 195).

Model PjBL membuat siswa dituntut untuk belajar melalui pengalaman langsung berdasarkan masalah. PjBL merupakan inovasi dalam pembelajaran karena dalam model PjBL kemampuan berpikir siswa betul-betul dioptimalisasi melalui proses kerja kelompok atau tim yang sistematis, sehingga siswa dapat memberdayakan, mengasah, menguji, dan mengembangkan kemampuan berpikirnya secara berkesinambungan. Model PjBL cocok dipadukan dengan pembelajaran 
tematik, khususnya pada kelas tinggi. Harapannya kegiatan ini dapat membantu siswa dalam mencapai kompetensi pembelajaran sedangkan guru bertindak sebagai fasilitator dan motivator.

Berdasarkan paparan di atas, RPP dengan model PjBL mampu membantu siswa mencapai kompetensi. Hal ini diperkuat dari hasil penelitian model PjBL yang dilakukan Karjiyati dkk (2017) dengan judul penelitian Pengembangan Model Project Based Learning dalam Pembelajaran Tematik Menggunakan Pendekatan Saintifik Untuk Mengembangkan Sikap Peduli Lingkungan dan Kreativitas Bagi Siswa SD, penelitian ini membahas tentang hasil penerapan model PjBL bagi siswa SD. Dari penelitian ini, hasil yang diperoleh model PjBL berpengaruh terhadap perkembangan sikap peduli lingkungan dan kreativitas siswa SD. Penelitian yang akan dilakukan peneliti adalah penelitian pengembangan dengan rencana pelaksanaan pembelajaran menggunakan model $\mathrm{PjBL}$ sebagai produk yang hanya sampai pada tahap uji coba tanggapan pengguna. Karena pada kondisi wabah Covid19 yang tidak memungkinkan untuk dilakukan eksperimen di sekolah.

Berdasarkan permasalahan di atas, peneliti tertarik untuk melakukan penelitian dan pengembangan model PjBL pada pembelajaran tematik di kelas IV SD yang berjudul "Pengembanngan Rencana Pelaksanaan Pembelajaran Menggunakan Model Project Based Learning (PjBL) pada Pembelajaran Tematik di Kelas IV SD Kota Bengkulu"

\section{Metode}

Dalam penelitian ini menggunakan jenis penelitian pengembangan. Rencana Pelaksanaan Pembelajaran (RPP) tematik menggunakan model PjBL ini memodifikasi model 4D (Four $D$ model) oleh Thiagarajan dan Sammel (dalam Winarni, 2018: 257). Penggunaan model ini didasari atas pertimbangan bahwa model ini dikembangkan secara prosedural sesuai dengan langkah-langkah yang sistematis.

Model 4D dikembangkan dengan mempertimbangkan beberapa alasan, yaitu: (a) model ini disusun secara terprogram dengan urutan kegiatan yang sistematis dalam upaya penyelesaian masalah belajar yang berkaitan dengan sumber belajar yang sesuai dengan kebutuhan dan karakteristik siswa, (b) pemilihan model pengembangan dengan pertimbangan bahwa model Thiagarajan pada bukunya "Instructional For Training Teacher of Expectional Childreen" membahas khusus bagaimana mengembangkan pembelajaran.

Pengembangan dengan model ini terdiri dari empat tahap, yaitu tahap pendefinisian (define), perancangan (design), pengembangan (develop), dan penyebaran (desseminate). Tahap pertama sampai ketiga yaitu pendefinisian, perancangan, dan pengembangan sering disebut sebagai bagian pengembangan, sedangkan bagian keempat sering disebut sebagai bagian penyebaran. Tetapi dalam pelaksanaan penelitian ini hanya sampai tahap pengembangan (develop) karena kondisi wabah Covid-19 yang tidak memungkinkan untuk dilakukan eksperimen di sekolah dan penyebarluasan (Disseminate) RPP yang telah dihasilkan pada tahap peengembangan.

Prosedur pengembangan yang dilakukan terdiri dari tiga tahap, yaitu tahap pendefinisian (define), perancangan (design) dan pengembangan (develop).

Adapun prosedur pengembangan RPP tematik menggunakan model PjBL ini dapat dilihat pada Gambar 3.1. 
Pada tahap pendefinisian yang meliputi:

1. Analisis awal akhir: menetapkan dan mendefinisikan kebutuhankebutuhan pembelajaran dengan menganalisis tujuan dan batasan materi.

2. Analisis siswa: mengidentifikasi karakteristik pembelajaran tematik kelas IV SD.

3. Analisis konsep: mengidentifikasi, merinci dan menyusun secara sistematis konsep pembelajaran.

4. Analisis tugas: menetapkan tugas yang akan diajarkan berdasarkan analisis awal-akhir.

5. Spesifikasi indikator pembelajaran.

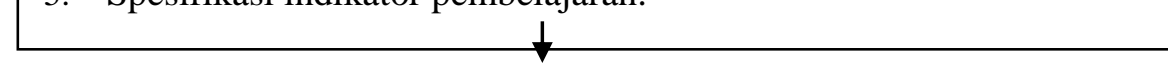

1. Merancang Indikator Pencapaian dan Tujuan Pembelajaran berdasarkan KD Muatan Mata Pelajaran dalam Pembelajaran yang telah ditetapkan.

2. Menentukan Materi, Pendekatan, Model, Metode, Media dan Sumber yang mendukung terlaksananya Pembelajaran.

3. Merancang Bahan Ajar berdasarkan materi.

4. Merancang Langkah-langkah Pembelajaran (Pembukaan, Inti dan Penutup) menggunakan model PjBL.

5. Merancang LKPD.

6. Merancang Lembar Penilaian Sikap.

7. Merancang Lembar Penilaian Pengetahuan.

8. Merancang Lembar Penilaian Keterampilan.

9. Merancang Penilaian Remedial dan Pengayaan.

10.Perencanaan awal produk rencana pelaksanaan pembelajaran (RPP)

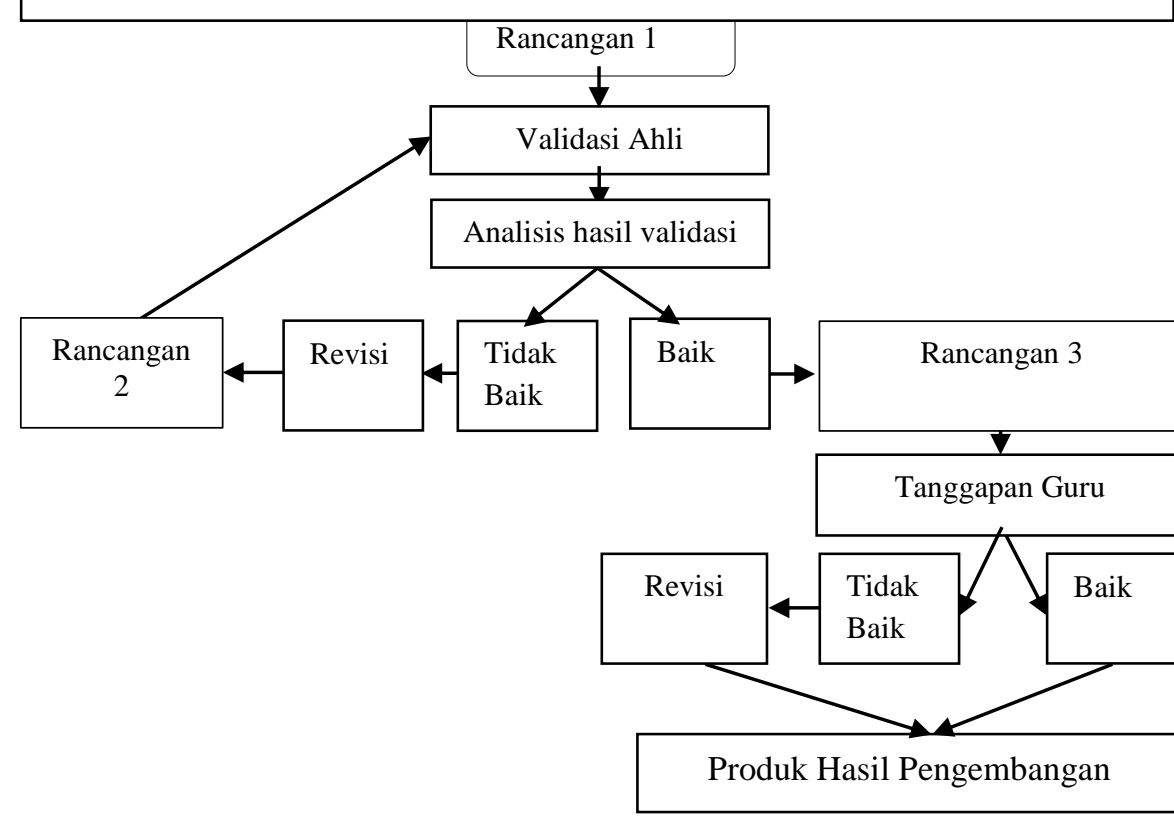

Gambar 3.1 Modifikasi RPP Model Pengembangan 4D Thiagarajam 
Instrumen digunakan untuk mengumpulkan data yang akan dianalisis sehingga hasilnya dapat memberikan gambaran bahwa RPP yang dikembangkan tersebut sudah baik atau belum. Instrumen penelitian dikembangkan dengan memperhatikan langkah-langkah penusunan RPP dan model PjBL.

Tabel 3.1 Aspek yang Dinilai, Instrumen, Data yang diamati, dan

Responden.

\begin{tabular}{|l|l|l|l|}
\hline Aspek yang Dinilai & Instrumen & Data yang Diamati & Responden \\
\hline $\begin{array}{l}\text { Hasil validasi RPP } \\
\text { Tematik } \\
\text { menggunakan model } \\
\text { PjBL }\end{array}$ & $\begin{array}{l}\text { Lembar } \\
\text { Validasi }\end{array}$ & Kevalidan RPP & $\begin{array}{l}\text { Ahli } \\
\text { pengembang } \\
\text { kurikulum dan } \\
\text { pembelajaran } \\
\text { SD }\end{array}$ \\
\hline $\begin{array}{l}\text { Tanggapan terhadap } \\
\text { RPP menggunakan } \\
\text { model PjBL }\end{array}$ & $\begin{array}{l}\text { Lembar } \\
\text { angket }\end{array}$ & $\begin{array}{l}\text { Tanggapan } \\
\text { Penggunaan terhadap } \\
\text { RPP }\end{array}$ & $\begin{array}{l}\text { Guru kelas IV } \\
\text { SD }\end{array}$ \\
\hline
\end{tabular}
berikut:

Instrumen-instrumen yang digunakan dalam penelitian ini adalah sebagai

\section{Lembar Validasi RPP}

Lembar validasi RPP digunakan untuk memperoleh masukan berupa penilaian, catatan, kritik dan saran terhadap rancangan awal (rancangan I) RPP dengan memberikan tanda $(\sqrt{ })$ pada baris dan kolom yang sesuai, serta menuliskan butir-butir saran dan kritik pada naskah RPP. Kemudian validator diminta memberikan penilaian secara umum terhadap RPP dengan kategori (1) Kurang, (2) cukup, (3) Baik dan (4) sangat baik.

\section{Angket Tanggapan Guru}

Angket respon guru digunakan untuk mengumpulkan data tentang respon guru terhadap rancangan II RPP yang dikembangkan.

Data ini akan dianalisis dan hasilnya akan digunakan untuk menyimpulkan apakah guru merespon secara positif atau tidak dalam menanggapi RPP Tematik menggunakan model PjBL yang telah dikembangkan. Sehingga data ini akan digunakan untuk merevisi rancangan II RPP menggunakan model PjBL menjadi RPP final.

\section{A. Teknik Analisis Data}

Analisis data yang digunakan pada penelitian ini adalah analisis deskriptif kualitatif dan statistik deskriptif.

\section{Analisis Deskriptif Kualitatif}

Analisis data deskriptif kualitatif digunakan untuk mengolah data berupa catatan, saran, atau komentar berdasarkan hasil penilaian yang terdapat pada lembar validasi ahli dan angket tanggapan guru.

\section{Analisis Statistik Deskriptif}

Analisis statistik deskriptif yang digunakan untuk menganalisa data berupa skor dari hasil validasi ahli dan angket tanggapan guru.

\section{a. Analisis Data Validasi Ahli}

Data validasi ahli RPP Tematik menggunakan model PjBL adalah data yang menggambarkan baik tidaknya RPP yang dikembangkan. Seluruh komponen RPP terlebih dahulu divalidasi oleh pakar (ahli), sebelum dipergunakan dalam penelitian. Instrumen validasi terdiri dari 4 skala kriteria penilaian, yaitu (1) Kurang, (2) cukup, (3) Baik dan (4) sangat baik.

Data kevalidan RPP akan dianalisis secara statistik deskriptif, dengan rumus berikut:

keterangan:

$$
V a=\frac{T S h}{T S e} \times 100
$$

$\mathrm{Va} \quad=$ Validasi dari ahli

TSh = Total skor maksimal yang diharapkan

TSE $=$ Total Skor Empiris 
Selanjutnya diberikan penafsiran dan pengambilan keputusan tentang kualitas produk pengembangan dengan menggunakan penilaian di bawah ini:

Tabel 3.2Konversi Tingkat Pencapaian dan Kualifikasi Validasi Ahli

\begin{tabular}{|l|l|l|}
\hline $\begin{array}{c}\text { Pencapaian } \\
\text { nilai (skor) }\end{array}$ & Kategori Penilaian & \multicolumn{1}{c|}{ Keterangan } \\
\hline $25.00-43.00$ & Kurang baik & Tidak boleh digunakan \\
\hline $44.00-62.00$ & Cukup baik & boleh digunakan setelah direvisi besar \\
\hline $63.00-81.00$ & Baik & Boleh digunakan setelah direvisi kecil \\
\hline $82.00-100$ & Sangat baik & Sangat baik untuk digunakan \\
\hline
\end{tabular}

(Akbar, 2013: 78)

Jika RPP masuk kategori tidak dan kurang baik, maka ada indikasi tidak bisa digunakan. Jika diperoleh kesimpulan cukup baik, maka ada indikasi perlu dilakukan revisi besar. Jika diperoleh kesimpulan baik, maka ada indikasi perlu dilakukan revisi kecil. Jika diperloleh kesimpulan sangat baik, maka ada indikasi sangat baik untuk digunakan. Selain berdasarkan kriteria penilaian yang telah ditetapkan, maka perlu tidaknya revisi juga memperhatikan catatan, saran, dan komentar dari validator.

\section{b. Analisis Data Tanggapan Guru}

Data tanggapan guru terhadap RPP adalah data yang menggambarkan tanggapan guru terhadap RPP Tematik menggunakan model PjBL. Pengambilan data ini menggunakan lembar angket yang dilakukan oleh peneliti kepada 8 guru kelas IV di kota Bengkulu. Tanggapan guru terhadap RPP terdiri dari 4 skala kriteria penilaian, yaitu (1) Kurang, (2) cukup, (3) Baik dan (4) sangat baik.

Data tanggapan guru terhadap RPP akan dianalisis secara statistik deskriptif, dengan rumus berikut:

$$
\begin{aligned}
& \qquad T p=\frac{T S h}{T S e} \times 100 \\
& \text { keterangan: } \\
& \text { Tp = Tanggapan guru } \\
& \text { TSh = Total skor maksimal yang diharapkan } \\
& \text { TSE = Total Skor Empiris }
\end{aligned}
$$

(Akbar, 2013: 158)

Selanjutnya diberikan penafsiran dan pengambilan keputusan tentang kualitas produk pengembangan dengan menggunakan kriteria tanggapan pengguna di bawah ini:

Tabel 3.4 Konversi Tingkat Pencapaian dan Kualifikasi Tanggapan Guru

\begin{tabular}{|l|l|l|}
\hline $\begin{array}{c}\text { Pencapaian } \\
\text { nilai (skor) }\end{array}$ & Kategori Penilaian & \multicolumn{1}{c|}{ Keterangan } \\
\hline $25.00-43.00$ & Kurang baik & Tidak boleh digunakan \\
\hline $44.00-62.00$ & Cukup baik & boleh digunakan setelah direvisi besar \\
\hline $63.00-81.00$ & Baik & Boleh digunakan setelah direvisi kecil \\
\hline $82.00-100$ & Sangat baik & Sangat baik untuk digunakan \\
\hline
\end{tabular}

(Akbar, 2013: 78)

Jika RPP masuk kategori tidak dan kurang baik, maka ada indikasi tidak bisa digunakan. Jika diperoleh kesimpulan cukup baik, maka ada indikasi perlu dilakukan revisi besar. Jika diperoleh kesimpulan baik, maka ada indikasi perlu dilakukan revisi kecil. Jika diperloleh kesimpulan sangat baik, maka ada indikasi sangat baik untuk digunakan. Selain berdasarkan kriteria tanggapan pengguna yang telah ditetapkan, maka perlu tidaknya revisi juga memperhatikan catatan, saran, dan komentar dari tanggapan pengguna. 


\section{Pembahasan}

Produk yang dihasilkan dalam penelitian pengembangan ini berupa RPP Tematik untuk pembelajaran tema 7 Indahnya Keragaman di Negeriku, subtema 3 Indahnya Persatuan dan Kesatuan Negeriku, pembelajaran 5. Dalam pembelajaran tersebut terdapat tiga muatan mata pelajaran yaitu PPKn dengan materi sikap toleransi dalam lingkungan, Bahasa Indonesia dengan materi menggali informasi dari teks bacaan, dan SBdP dengan materi pembuatan karya seni montase. RPP dikembangkan menggunakan langkah-langkah model pembelajaran yang sesuai dengan pembelajaran tersebut yaitu model PjBL. Model PjBL berisikan konsep tentang kegiatan berproyek dalam proses pembelajarannya agar pembelajaran yang melibatkan proyek atau menghasilkan produk dapat berjalan dengan baik. Model PjBL sangat baik digunakan dalam pengembangan RPP agar tujuan pembelajaran berproyek dapat tercapai. Sejalan dengan hal itu, Surya (2018: 52) dalam penelitiannya menyatakan bahwa penggunaan model pembelajaran Project Based Learning (PjBL) dapat meningkatkan hasil belajar dan kreatifitas siswa pada pembelajaran tematik di SD. Penjabaran tersebut menjelaskan bahwa model PjBL sesuai dengan pembelajaran tematik.

Seperti yang diungkapkan oleh Rusman (2016: 139) bahwa pembelajaran tematik merupakan suatu sistem pembelajaran yang memungkinkan siswa, baik secara individual maupun kelompok, aktif menggali dan menemukan konsep serta prinsip-prinsip keilmuan secara holistik, bermakna, dan autentik. Selain itu, model PjBL mampu memadukan semua mata pelajaran yang dipadukan dalam tema untuk diajarkan tanpa pengotak-kotakan mata pelajaran. Hal tersebut sejalan dengan pengertian pembelajaran tematik yang diungkapkan oleh Hidayah (2015: 48) yang menyatakan bahwa pembelajaran tematik adalah pembelajaran terpadu yang menggunakan tema untuk mengaitkan beberapa mata pelajaran sehingga dapat memberikan pengalaman bermakna kepada siswa. Materi pembelajaran yang dapat di padukan dalam satu tema selalu mempertimbangkan karakteristik siswa seperti minat, kemampuan, kebutuhan, dan pengetahuan awal.

Proses pengembangan RPP Tematik menggunakan modle PjBL pada pengembangan model 4D Thiagarajan (Winarni, 2018: 257) yaitu meliputi kegiatan pendefinisian (define), perancangan (design), pengembangan (development) dan penyebaran (dessiminate). Namun, pada penelitian kali ini hanya sampai pada tahap pengembangan saja tidak sampai pada tahap penyebaran, karena untuk sampai pada tahap penyebaran maka harus dilakukan uji coba lebih dari satu kali dan dengan subjek penelitian yang berbeda, sedangkan penelitian ini dilaksanakan pada masa Pandemi Covid-19 sehingga tidak memungkinkan untuk melaksanakan tahap penyebaran. Pelaksanaan Penelitian pengembangan ini dimulai dari tanggal 15 Juni sampai 15 Juli 2020.

Pada tahap pendefinisian (define) ini dilakukan dengan lima tahap, yaitu (1) analisis awal akhir; (2) analisis siswa; (3) Analisis Konsep; (4) analisis tugas dan (5) spesifikasi indikator pembelajaran. Analisis awal akhir dilakukan melalui observasi kelas, peneliti memperoleh informasi mengenai masalah dasar dalam pembelajaran Tematik yang dialami oleh guru, meliputi suasana kelas ketika pembelajaran yang kurang baik dan cara penyampaian materi oleh guru. Hal ini diperkuat oleh Oktavia (2014: 830) yang menyatakan bahwa keseharian guru belum sepenuhnya menggunakan media dalam pembelajaran, masih banyak guru yang hanya mengandalkan metode ceramah, masih ada guru yang kurang mampu dalam pengelolaan kelas dan tidak menggunakan model. Selain itu masih ada guru yang hanya mengandalkan ruang kelas sebagai ruang pembelajaran dan masih banyak guru yang belum mampu menunjang keberhasilan siswa.

Setelah dilakukan kajian terhadap pembelajaran di kelas, selanjutnya peneliti melakukan analisis siswa. Siswa yang dianalisis adalah siswa kelas IV SD yang tergolong dalam masa kanak-kanak yang berumur 7-11 tahun. Dalam 
kelompok ini anak berada dalam tahap operasional konkret (Wiarsih, 2013). Sehingga siswa akan sangat mudah mencapai tujuan pembelajaran dengan memeragakan langsung konsep-konsep yang dipelajari, tidak hanya mempelajari teorinya saja.

Hasil dari analisis siswa digunakan sebagai pijakan peneliti dalam menentukan materi pembelajaran yang akan dilakukan pengembangan menggunakan model PjBL. kemudian menganalisis tugas dan melakukan spesifikasi indikator pembelajaran. Informasi yang telah diperoleh dari tahap pendefinisian peneliti gunakan sebagai acuan untuk melaksanakan tahap selanjutnya yakni tahap perancangan (design).

Pada tahap perancangan (design) peneliti merancang RPP dan menyusun instrument penelitian yang akan dilakukan pengembangan. Pada tahap perancangan RPP, peneliti merancang RPP berdasarkan komponen, prinsip dan langkah-langkah penyusunan RPP yang terdapat dalam Permendikbud nomor 22 Tahun 2016. Setelah selesai pada tahap perancangan awal, selanjutnya RPP Rancangan I akan divalidasi pada tahap pengembangan. Pada kegiatan penyusunan Instrumen Penelitian, Peneliti membuat instrument validasi ahli dan tanggapan guru yaitu dengan membuat angket penilaian tertutup menggunakan skala likert. Angket penilaian validasi ahli dan tanggapan guru dibuat berdasarkan komponen yang ada dalam RPP dan telah dikonsultasikan ke dosen pembimbing.

Tahap selanjutnya yakni pengembangan (development). Dalam tahap pengembangan ini meliputi penilaian validasi ahli dan tanggapan guru. Peneliti membuat instrument validasi dan tanggapan guru yaitu membuat angket penilaian tertutup menggunakan skala likert. Penilaian validasi dan angket tanggapan guru dibuat berdasarkan komponen yang ada dalam RPP dan telah dikonsultasikan ke dosen pembimbing.

Validasi Ahli dilakukan sebanyak dua tahap, yaitu tahap I dan tahap II. Penilaian pada tahap I ini terdapat 15 aspek penilaian yang mendapat nilai 3 dan 5 aspek penilaian mendapat nilai 4 dari nilai maksimal 4. Pada validasi ahli tahap I ini, nilai yang didapat yaitu sebesar 78.13 dari rentang nilai 100. Selanjutnya nilai tersebut dikonversikan pada tingkat ketercapaian produk, maka hasilnya dalam kriteria baik. Pada tahap I, hasil penilaian, saran dan masukan dari ahli digunakan untuk merevisi RPP Rancangan 1 yang akan menghasilkan RPP Rancangan 2. Berdasarkan tabel 4.4 yaitu tentang saran dan komentar dari ahli, RPP masih terdapat banyak revisi pada beberapa komponen. Hal ini dikarenakan karena dalam rancangan 1 ini, terdapat ketidaksesuaian antar komponen dalam RPP tersebut, masih banyak kata yang salah dalam penulisan dan susunan yang kurang rapi. Setelah dilakukan revisi berdasarkan hasli validasi tersebut, kemudian RPP rancangan 2 akan divalidasi kembali oleh ahli pada tahap II.

Pada tahap II, Rancangan 2 divalidasi kembali oleh ahli. Penilaian pada tahap II ini terdapat 3 aspek penilaian yang mendapat nilai 3 dan 17 aspek penilaian mendapat nilai 4 dari nilai maksimal 4 . Nilai yang diperoleh pada tahap ini yaitu 95.63 dari rentang nilai 100. Selanjutnya nilai tersebut dikonversikan pada tingkat ketercapaian produk, maka hasilnya dalam kriteria sangat baik. Hasil revisi dari ahli inilah yang akan digunakan untuk merevisi RPP Rancangan 2 menjadi RPP Rancangan 3. Saran dan masukan pada validasi tahap 2 ini tidak banyak, sehingga setelah dilakukan revisi, tidak harus konsultasi kembali ke ahli dan nilai yang didapat dari ahli masuk dalam kategori sangat baik. Kemudian RPP rancangan 3 akan diberikan kepada guru untuk dimintai pendapatnya terhadap RPP yang telah divalidasi oleh ahli tersebut.

Tahap berikutnya yaitu RPP Rancangan 3 diberikan kepada guru untuk diberi tanggap an menggunakan angket tertutup. Pemberian angket dilakukan pada delapan guru heterogen dari empat sekolah dengan dua sekolah terakreditasi A dan dua sekolah terakreditasi B. Karena data diambil dari sekolah yang heterogen, hasil penilaian juga heterogen. Nilai terendah yaitu sebesar 80.26 sedangkan nilai tertinggi yaitu sebesar 93.42. Rata-rata hasil penilaiannya yaitu 87.66 dari rentang 
nilai 100. Setelah dikonversi dengan kriteria penilaian, hanya ada satu guru yang memberikan nilai dalam kategori baik dan tujuh guru lainnya dalam kategori sangat baik. Jika dilihat pada rata-rata skor penilaian, maka nilai yang diperoleh dalam kategori sangat baik sebagai produk final pengembangan. Dari semua guru yang menilai RPP Rancangan 3, tidak ada saran yang mengharuskan adanya revisi terhadap RPP tersebut, sehingga secara tidak langsung RPP rancangan 3 menjadi produk final pengembangan.

\section{Referensi}

Abidin, Y. (2014). Desain Sistem Pembelajaran dalam Konteks Kurikulum 2013. Bandung: PT. Refika Aditama.

Akbar, Sa'dun. (2013). Instrumen perangkat pembelajaran. Bandung: Remaja Rosdakarya

Daryanto dan Karim, S. (2017). Pembelajaran Abad 21. Yogyakarta: Gava Media.

Fathurrohman, M. (2015). Model-Model Pembelajaran Inovatif. Yogyakarta: Ar-Ruz Media.

Hartini, Ayu., (2017), Pengembangan Perangkat Pembelajaran Model Project Based Learning untuk Meningkatkan Kemampuan Berpikr Kritis Siswa Sekolah Dasar, Jurnal Pendidikan dan Pembelajaran Sekolah Dasar, Vol. 1, No. 2, hal: 7-16.

Hidayah, Nurul., (2015), Pembelajaran Tematik Integratif di Sekolah Dasar, Pendidikan dan Pembelajaran Dasar, Vol. 2, No. 1, hal: 34-49.

Kadir, A., Asrohah, H. (2014), Pembelajaran Tematik. Jakarta: Rajawali Pers.

Karjiyati, V., \& Neza Agusdianita, (2017), Pengembangan Model Project Based Learning dalam Pembelajaran Tematik Menggunakan Pendekatan Saintifik Untuk Mengembangkan Sikap Peduli Lingkungan dan Kreativitas Bagi Siswa SD, Jurnal Pendidikan Guru Sekolah Dasar, Vol. 10, No. 2.

Kemdikbud. (2014). Materi pelatihan guru implementasi kurikulum 2013. Jakarta: Kementerian Pendidikan dan Kebudayaan

Kemdiknas. (2010). Pengembangan Pendidikan Budaya dan Karakter Bangsa. Badan Penelitian dan Pengembangan: Pusat Kurikulum.

Muri, Lidia., Marzuki, \& Rosnita, (2018), Pengembangan Bahan Ajar Ilmu Pengetahuan Alam Project Based Learning di Sekolah Dasar Negeri Pontianak. Jurnal Pendidikan dan Pembelajaran Khatulistiwa, Vol. 7, No. 4, hal: $1-9$

Oktavia, Yanti., (2014), Usaha Kepala Sekolah dalam Meningkatka Kreativitas Guru dalam Pembelajaran Di Sekolah Dasar, Jurnal Administrasi Pendidikan, Vol 2, No. 1, Hal: 808-831.

Rusman. (2016). Pembelajaran Tematik Terpadu Teori, Praktik dan Penilaian Jakarta: Rajawali Pers 
Prasetyo, J., Dadi, S., Anggraini, D.

Sani, Ridwan Abdullah. (2014), Pembelajaran Saintifik untuk Implementasi Kurikulu 2013. Jakarta: PT Bumi Aksara.

Satrianawati. (2017). Metode Pembelajaran utuk Keterampilan Abad 21.

Solekhah, Siti., (2014), Implementasi Pembelajaran Tematik di SD Muhammadiyah Program Khusus Surakarta, Jurnal Ilmiah Pendidikan Sos Ant, Vol. 4, No. 1.

Sugiyono. (2013). Metode Penelitian Kuantitatif, Kualitati, dan R\& D. Bandung: Alfabeta

Surya, Andita Putri, Stefanus C. Relmasira., Agustina Tyas Asri Hardini. (2018). Penerapan Model Pembelajaran Projrct Based Learning (PjBL) untuk menungkatkan Hasil Belajar dan Kreativitas Siswa Kelas III SD Negeri Sidorejo Lor 01 Salatiga. Jurnal Pesona Dasar. Aceh: Universitas Syiah Kuala. Vol. 6, No. 1, hal: 41-54.

Tinenti, Y., R. (2018). Model Pembelajaran berbasis proyek (PBP). Yogyakarta: Deepublish.

Wiarsih, Nur., (2013), Project Based Learning untuk Meningkatkan Motivasi Belajar Peserta Didik, Ar-Risalah, Vol. xi, No. 1, hal: 78-86.

Winarni, E., W. (2011). Penelitian Pendidikan, Bengkulu: FKIP UNIB Press

(2018). Pendekatan Ilmiah dalam Pembelajaran Kreatif dan Inovatif. Bengkulu: Unit Penerbitan FKIP UNIB

(2018). Teori dan Praktik Penelitian Kuantitatif, Kualitatif, PTK, R\&D. Jakarta: Bumi Aksara. 